\title{
Certain Relationships between Chemical Composition and Properties of Petroleum Asphalts from Different 0 rigin
}

\author{
L.O. O yekunle ${ }^{1}$ \\ 1 Department of Chemical Engineering, University of Lagos, Lagos 101017 - Nigeria \\ e-mail: layioyekunle@yahoo.com
}

\begin{abstract}
Résumé - Des relations entre la composition chimique et les propriétés de bitumes d'origines différentes - Les bitumes sont habituellement classés selon trois propriétés physiques : ductilité, pénétration et point de ramollissement. L'étude présentée ici démontre à travers plusieurs exemples que ces traits physiques ne sont pas assez distinctifs. Il a été découvert que la composition chimique apporte davantage d'enseignements sur les différentes propriétés physiques des bitumes. On note des différences remarquables entre la composition chimique de bitumes de même point de ramollissement et de même origine. Une plus grande ductilité provient d'une plus forte teneur en résines alors qu'une pénétration moindre est la conséquence d'une plus grande teneur en asphaltènes. La corrélation de deux indices et de la composition de bitumes révèle que l'indice Gaestël (1 $\left.1_{c}\right)$ est un meilleur paramètre de caractérisation de bitumes que l'indice d'asphaltène $\left(1_{\mathrm{A}}\right)$. Ces deux indices peuvent être utilisés comparativement pour distinguer des bitumes ayant des points de ramollissement voisins.
\end{abstract}

\footnotetext{
Abstract - Certain Relationships between Chemical Composition and Properties of Petroleum Asphalts from Different Origin - Asphalts are classified according to three most commonly measured properties: ductility, penetration and the ring and ball softening point. The present study shows through many examples that these physical characteristics are not discriminating enough. It was revealed that the chemical composition sheds more light on the physical properties of the various grades of asphalt. There were significant differences between the chemical composition of asphalts having the same softening point and from the same origin. Increase in ductility has been accounted for by the high content of resins while lower penetration is due to high asphaltene content. The correlation of two asphalt indices with the composition shows that the Gaestel index $\left(I_{C}\right)$ proves to be a more adequate quality parameter than the asphaltene index $\left(I_{A}\right)$ for the characterization of asphalts. Both indices can be comparatively used to distinguish between asphalts of narrow softening point ranges.
} 


\section{IN TRO DUCTIO N}

\section{PETRO LEUM ASPHALTS}

Asphalt is of particular interest because of its many engineering and industrial applications. It is a strong cement, readily adhesive, highly waterproof and durable. It is a plastic substance that imparts controllable flexibility to mixtures of mineral aggregates with which it is usually combined and used for the construction of road networks, international highways, airfields, reservoirs, irrigation channels and as roofing materials. Pipelines and electrical cables are protected with asphalt.

Crude oils are classified as heavy, medium or light depending on the level of asphaltic materials present in a particular crude. Refining of asphaltic and mixed base crude oils produces petroleum asphalts; the process employed depends on the nature of the crude and the grades of asphalt desired. The oldest and most widely used method is the atmospheric vacuum distillation of suitable crudes that result in the production of straight-run residual asphalts. Upgrading of low-grade asphalts is usually carried out by the airblowing process to give oxidized or semi-blown products. Chemical treatment of one cut or a blend of different cuts will produce asphalts with special properties that are not imparted by the distillation process. When several processes are applied to one or more crudes, the resultant asphalt blends have properties far superior to those obtained when only one manufacturing process is used [1-9].

\subsection{Characteristic Properties of Asphalts}

Asphalts are characterized by a number of physical properties of which the three most widely used are ductility, penetration, ring and ball softening point. Further tests include specific gravity, molten viscosity, molecular weight, Fraas breaking point, wax content, penetration index, and loss on heating. Other important determinations are temperature susceptibility, cold fragility, viscosity before and after aging, interfacial tension, adhesion, cohesion, electrical resistance, impermeability to water and solubility in benzene.

\subsubsection{Ductility}

It is a measure of the capacity of asphalt to elongate or stretch and it is an indication of the material to flow. A briquette of the asphalt is pulled apart at a uniform rate at a specified temperature (usually $25^{\circ} \mathrm{C}$ ), and the elongation before rupture takes place measured in centimeters (ASTM D113) [10,11].

\subsubsection{Penetration}

This is measured with a penetrometer by which a standard needle is applied to the sample. It is the distance in tenths of a millimeter that a needle penetrates vertically into the sample under fixed conditions of temperature, load and time (ASTM D5) $[10,11]$.

\subsubsection{Softening Point}

The softening of asphalts does not take place at a definite temperature. As the temperature is raised asphalts gradually and imperceptibly change from a brittle or exceedingly thick and slow-flowing material to a softer and less viscous liquid. The softening point is defined as the temperature at which a disk of the sample held within a horizontal ring is forced downward a distance of $2.54 \mathrm{~cm}$ under the weight of a steel ball (ASTM D 36) [10,11].

\subsection{Chemical Composition of Asphalts}

Asphalts are complex mixtures containing many different molecular species whose nature varies according to the crude oil sources. The composition of asphalts and other heavy fractions has been the subject of several investigations over the years [2-9, 12-39]. The method of production greatly influences its structure $[40,41]$ and the chemical composition of asphalt determines its properties and the final end uses.

The separation of asphalts into different chemical groups has been made by both physical and chemical methods [111]. The fractions so obtained are made up of poly-nuclear aromatics and hetero-aromatic molecules (asphaltenes), viscous naphtheno-aromatic hydrocarbons (heavy oils), heterocyclic and polar compounds (resins). The relative amount of asphaltenes, oils and resins obviously depends on two main parameters: the crude source and the manufacturing processes.

\subsubsection{Asphaltenes}

They are the most complex molecules present in asphalts and are regarded as being formed by the condensation of resins. They are black or brown colored, hard, non-plastic, nonmaleable, high molecular weight compounds ranging between 1200 and 200,000. They contain predominantly carbon and hydrogen with sulfur, oxygen, nitrogen and other heteroatoms. Asphaltenes are agglomerations of the most highly polar molecules and they are responsible for the presence of structure in asphalts. They are insoluble in low molecular weight normal paraffins and are classified by the precipitating solvent; different solvents precipitating different amount of asphaltenes. They impart strength, stiffness and colloidal structure in asphalt. They are determined by ASTM D327 as the n-heptane insolubles [10,11].

\subsubsection{Heavy 0 ils}

The remaining portion of an asphalt material after the precipitation of asphaltenes with the normal paraffins is known as maltenes. It consists of two fractions, heavy oils and resins [2-6, 12-18]. These oils are the liquid part of the 
asphalt and consist of normal-, iso- and cyclo-paraffins and condensed naphthenes with some alkyl aromatics. The aromatic portion is mostly naphtheno-aromatic hydrocarbons with three or four naphthenic rings per molecule. The fraction is non-polar. The oils have a key feature of dispersing polar agglomerations of asphaltenes and resins. This is especially true of the aromatic and naphthenic oils. Thus, this component is very important and it is responsible for viscosity and fluidity of the asphalt.

\subsubsection{Resins}

The resins are semiliquid and sometimes solid materials of dark red color at room temperature. They are chemically very similar to the asphaltenes; present in resins are carbon, hydrogen, oxygen, sulfur, nitrogen and many other elements including metals. The resins consist of mainly polycylic molecules containing saturated, aromatic and hetero-aromatic rings and heteroatoms in various functional groups. The resins are not as polar as the asphaltenes and their molecular weight ranges from 300 to 2000. These resins provide adhesion, ductility, malleability and plasticity.

\subsection{Colloidal Stability of Asphalts}

Asphalt is a colloidal system in which the most important structure forming elements are the asphaltenes, which are dispersed in the maltenes. The size of the colloidal particles has been determined using different techniques: ultrafiltration, electron microscopy, small angle X-ray scattering and others $[42,43]$. The size of the asphaltenes particles ranges from 4 to $10 \mathrm{~nm}$ and that of asphaltenes micelles varies 15 to $30 \mathrm{~nm}$. Two key parameters that control the stability of asphaltene micelles are the ratio of aromatics to saturates and that of resins to asphaltenes. When these ratios decrease, asphaltene micelles will coalesce and form larger aggregates. These two ratios are explored in the evaluation of relationship between the group chemical composition and the physical properties of asphalts. They are expressed in terms of two indices: asphaltene index and Gaestel index.

\section{Asphaltene Index, $I_{A}$}

This is the changing rate of asphaltene content and it is calculated using normal heptane asphaltene precipitation. The ASTM D3279 for n-heptane insolubles is the most common and widely used method [2,5,9-13]. When assessing the colloidal stability of asphalts, the main factor taken into account is the content of asphaltenes; consequently, the asphaltene index can be found suitable:

$$
I_{A}=\frac{\text { Asphaltenes }+ \text { Resins }}{\text { Saturates }+ \text { Aromatics }}
$$

Gaestel Index, $I_{C}$

The resins play an important role in the stability of asphaltenes. They are believed to disperse the asphaltenes, preventing them from separation as a separate phase. The solubilizing power of the resins is affected by the degree of aromaticity in the molecules. The stability of asphalt may be described by the Gaestel instability index, which shows the dispersing capability of maltenes to asphaltenes [34, 43, 44]. This is also evaluated using n-heptane asphaltenes.

$$
I_{C}=\frac{\text { Saturates }+ \text { Asphaltenes }}{\text { Resins }+ \text { Aromatics }}
$$

When the value of $\mathrm{I}_{\mathrm{C}}$ increases, colloidal stability decreases. Thus, the colloidal stability index should be found primarily helpful when comparing the stabilities of different asphalt samples.

\section{Asphalt Rejuvenating}

It is characteristic of asphalts, in paving mixtures of all types, to change in composition with time [32-38]. This process, referred to as aging, is generally a gradual one with the rate and degree of change dependent on the original chemical composition of the asphalt, its environmental conditions, and length of exposure to weathering. The asphalt colloidal stabilities deteriorate clearly with resins and asphaltenes as the more unstable constituents [34]. Addition of suitable components such as selected fractions of petroleum oils and resins, at the appropriate time during the aging process can stop aging by reconstitution of the weathered asphalt and returning it to its original condition. This is accomplished by restoring the balance of the two major constituents in asphalt: asphaltenes and maltenes; hence the importance of compositional studies.

\subsection{Previous Studies on Asphalts}

Oyekunle and others [5, 46-59] have carried out various studies on the physical characteristics and chemical composition of asphalts. Investigation of the residual asphalts produced from twenty-three Nigerian crude oil samples revealed that these asphalts have low asphaltene contents (1.52 - 6.0 wt.\%) with softening points varying between $25-$ $66.5^{\circ} \mathrm{C}(\mathrm{R} \& \mathrm{~B})$ and penetration values of $26-300(0.1 \mathrm{~mm})$ and above at $25^{\circ} \mathrm{C}[46,48,58]$.

Air-oxidation, chemical and catalytic treatment of the residual asphalts at temperatures of $210-250^{\circ} \mathrm{C}$ led to generation of asphaltenes resulting in manifold increases in the viscosity of the treated samples. The asphaltene content multiplied by 5 - to 10 -fold while there were more than $20 \%$ increases in softening point $[51-53,55,56,59]$.

Rheological studies were conducted on a number of oxidized asphalts produced from Russian crudes [50]. The flow properties of eighteen (18) asphalt samples were examined using a rotational viscometer (Rotovisco of Gebruder Haake, West Germany) at elevated temperatures $100-200^{\circ} \mathrm{C}$. The asphalts exhibited complex rheological 
properties: non-Newtonian and pseudoplastic character at low shear rates. A Newtonian behavior was approached at high shear rates with increasing temperature.

A careful study of the relationship between softening point, penetration and viscosity at high temperatures of 100$200^{\circ} \mathrm{C}$ for eleven (11) Russian asphalt samples revealed that viscosity measurement is much more accurate than other physical parameters [49]. It was discovered that viscosity at $140^{\circ} \mathrm{C}$ could conveniently replace the empirical parameters and could be used on-line for process control. The viscosity (at $140^{\circ} \mathrm{C}$ ) and softening point correlation was closely examined for seventy-one (71) asphalt samples in the softening point range of $40-60^{\circ} \mathrm{C}$ [54]. The best correlation was achieved over narrow softening point range (within 10$15^{\circ} \mathrm{C}$ ) for asphalts from the same region (or source). Two mathematical models relating softening point/penetration and softening point/viscosity were proposed by Oyekunle and Omatsone [57]. The latter model with viscosity measurement at $140^{\circ} \mathrm{C}$ gave better results.

A study of the composition of three paving asphalts of very close softening points $\left(48-49^{\circ} \mathrm{C}\right)$ revealed that asphalts are clearly distinguished by their group chemical composition [46]. There were differences between the contents of oils, resins and asphaltenes for each sample. The asphaltene content alone did not fully explain the rheological behavior of the asphalts while other contributory factors were asphaltenes/resin ratio and the degree of aromaticity of the oils.

\section{Present Study}

It is the chemical composition of asphalt that determines its properties and its final end uses. Thus, a comprehensive study of the nature of asphaltenes and resins and the determination of the main relationships in their composition, structure and properties are necessary for the solution of a number of important theoretical and practical problems. Numerous publications dealing with the extensive study of asphaltenes and resins chemical functionalities have been reported in the open literature in recent times. These studies have focused on the nature, the chemical and structural characterization of asphaltenes and resins and their relation to asphaltene stability. The present study is aimed at the correlation of asphalt properties making use of a system of parameters relating the chemical composition of paving asphalts of different origins with the generally accepted criteria. This type of study will ultimately lead to a more thorough understanding of the chemical composition as seen through the physical properties.

\section{SOURCES OF THE DATA USED FOR ANALYSIS}

The data used in this work were obtained from a number of experimental studies as shown in Table 1.

\section{Materials and Methods}

The materials analyzed were both oxidized and residual asphalts produced directly from different refineries or obtained from pilot plants as shown in Table 1. The five fresh paving residual asphalts were obtained from heavy Chinese crude oil. The determination of general physical properties was made according to the ASTM methods $[1-3,5,6,10$, 11]. Viscosity was evaluated from the shear stress/shear rate data at various temperatures $\left(100-200^{\circ} \mathrm{C}\right)$ using a rotational viscometer $[5,47,49]$.

\section{Asphalt Fractionation}

The asphalt samples were fractionated into asphaltenes and maltenes using n-heptane (ASTM D3279). The asphaltenes were precipitated while the soluble maltenes were obtained

TABLE 1

Data sources for the different asphalts

\begin{tabular}{c|l|c|c|c}
\hline S/N & Crude source & No. & Softening points & Reference \\
\hline 1. & Western Siberia & 6 & $41-99.5$ & {$[2]($ p. 227$)$} \\
2. & Tataria & 7 & $45-53$ & {$[2]($ p. 225) } \\
3. & Tataria & 6 & $50-51$ & {$[2](\mathrm{p} .230)$} \\
4. & Arlan-Chekmagush & 4 & $42-53.5$. & {$[6]$} \\
5. & Worldwide & 22 & $39.5-95.5$ & {$[8]$} \\
6. & Arlan, Romashkino, W/Siberia, Syria & 15 & $37-55$ & {$[9]$} \\
7. & Russian & 3 & $48-49$ & {$[40]$} \\
8. & Tataria & 7 & $39-73$ & {$[42]$} \\
9. & Romashkino/Western Siberia & 4 & $45-82$ & {$[43]$} \\
10. & Tataria/Romashkino/W.Siberia & 8 & $39-101$ & {$[39]$} \\
11. & Urals and Venezuela & 2 & 47 & {$[32]$} \\
12. & Chinese Fresh asphalts & 5 & $43.5-45.8$ & {$[42]$} \\
\hline
\end{tabular}


as filtrates and subsequently fractionated by liquid chromatography into resins, aromatics and saturated fractions. The resins were first adsorbed and eluted from solid adsorbents followed by the recovery of the oils. The oils were fractionated into other components: saturates, monocyclic aromatics, bicyclic aromatics and polycyclic aromatics.

\section{RESULTS AND DISCUSSION}

\subsection{Physical Characteristics of Asphalts}

Ductility, penetration and softening point are the most easily used tests for the identification of different grades of asphalts. They are extensively used for the purposes of refinery control. The relationship between the two major properties of asphalts is indicated in Figure 1. These are eleven (11) oxidized residual asphalts produced from crude oil mixtures obtained from Tataria and Romashkino/Western Siberia. The common feature of the behavior of these asphalts is that penetration decreases with increasing ring and ball softening point (S.P.). These are the general observations usually recorded for asphalts of wide softening point ranges $\left(\right.$ S.P. $\left.=39-82^{\circ} \mathrm{C}\right)$. Some correlations have been developed to describe the softening point/penetration and softening point/viscosity relationships for typical asphalts [54, 57].

Table 2 shows the clear picture of property variation for six asphalt samples having the same softening point $\left(49^{\circ} \mathrm{C}\right)$ produced by different methods. They are observed to vary considerably in their physical properties with ductility as the most widely varying parameter compared to the two penetrations. This property variation can only be explained by the differences in their chemical composition.

TABLE 2

Physical properties of oxidized for asphalts

\begin{tabular}{l|c|c|c|c|c|c}
\hline Sample & 1 & 2 & 3 & 4 & 5 & 6 \\
\hline S.P. (R \& B), ${ }^{\circ} \mathrm{C}$ & 49 & 49 & 49 & 49 & 49 & 49 \\
\hline Ductility & 102 & 100 & 86 & 80 & 70 & 56 \\
\hline Pen @ $25^{\circ} \mathrm{C}$ & 63 & 65 & 81 & 77 & 75 & 74 \\
\hline Pen @ $0^{\circ} \mathrm{C}$ & 18 & 20 & 27 & 32 & 25 & 27.5 \\
\hline
\end{tabular}

\subsection{Chemical Composition and Physical Properties}

The physico-chemical characteristics of four oxidized asphalts (S.P. $=42-53.5^{\circ} \mathrm{C}$ ) shown in Figure 2, reveal that both penetration at $25^{\circ} \mathrm{C}$ as well as ductility vary significantly with the softening point. All the compositional parameters and the two asphalt indices, $\mathrm{I}_{\mathrm{A}}$ and $\mathrm{I}_{\mathrm{C}}$, show some remarkable changes with the softening point.

A distinguishable feature of the general relationship between ductility and the content of resins is seen in Figure 3 for two groups of asphalts (S.P. $=49-50.5$ and S.P. $=50$ $51^{\circ} \mathrm{C}$ ) Ductility increases with the content of the resins in a non-linear manner, hence, it can be deduced that resins determine ductility.

Further confirmation of the relationship between the different asphalt characteristics are shown in Figure 4 for four Chinese fresh residual asphalts of narrow softening point range (S.P. = 43.5-45.8). As expected, penetration decreases

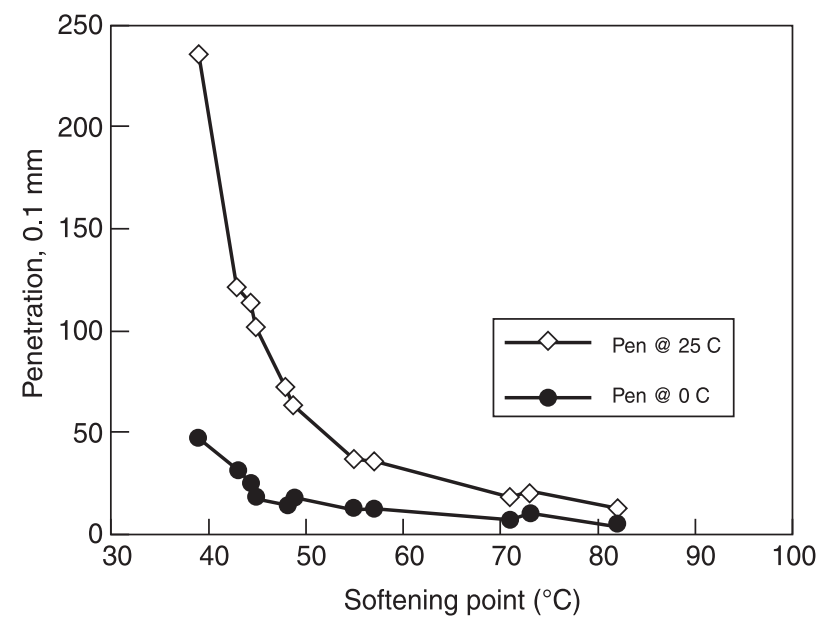

Figure 1

Physical properties of asphalts.

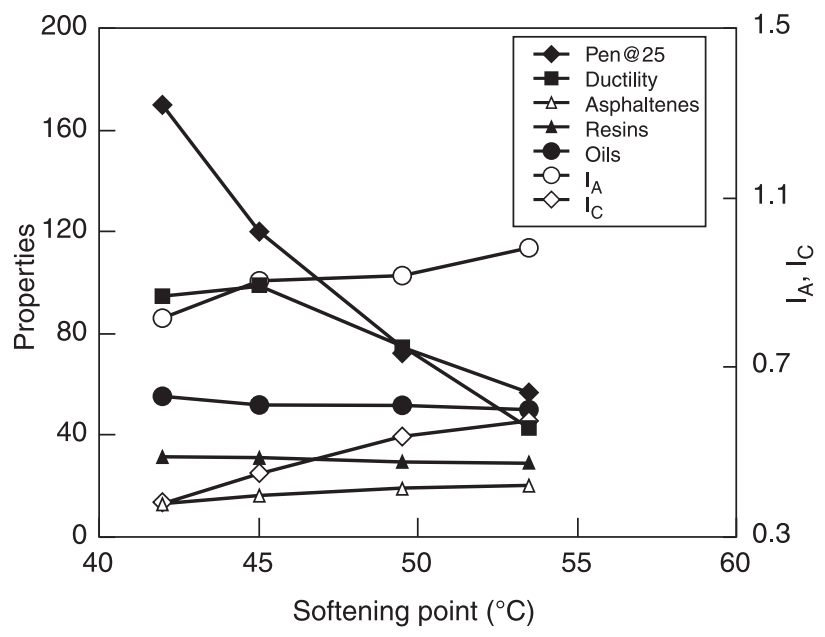

Figure 2

Chemical composition and indices of residual asphalts $($ S.P. $=42-53.5)$. 


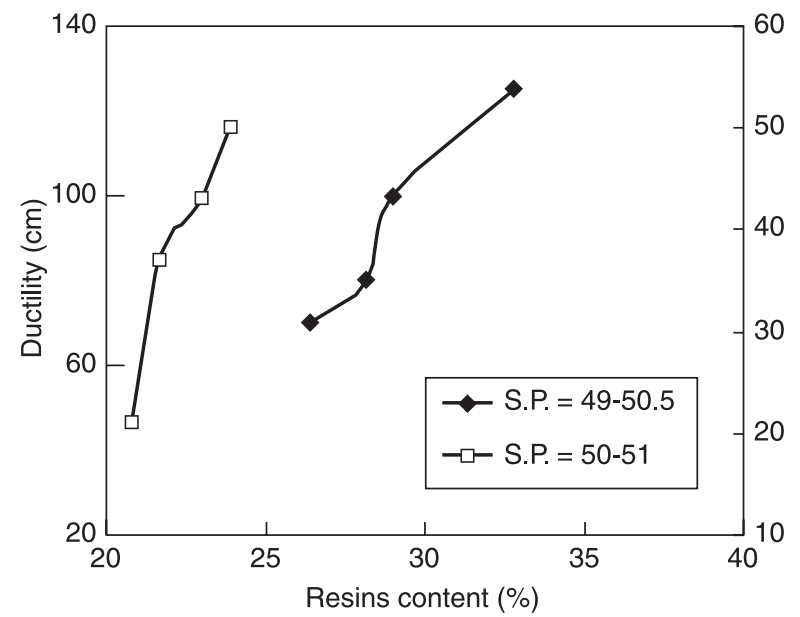

Figure 3

Dependence of ductility on resins content.

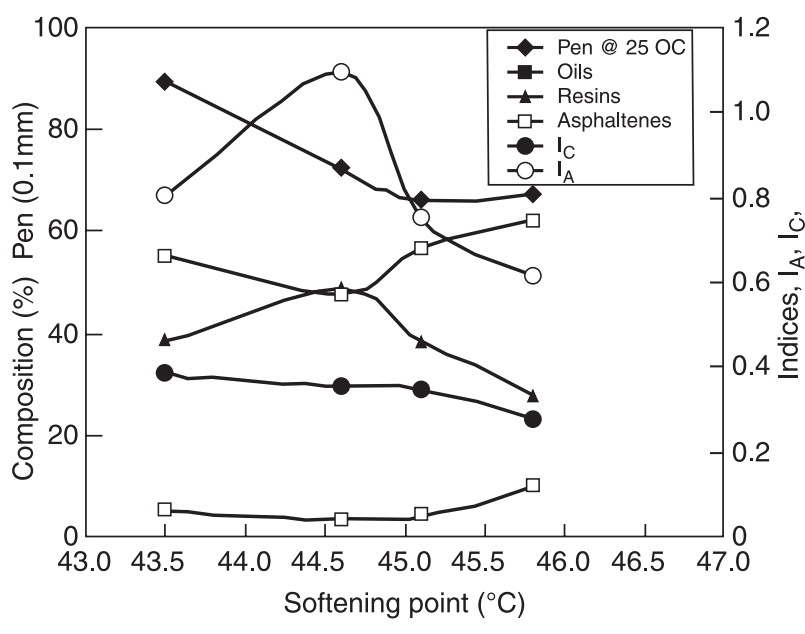

Figure 4

Asphalt characteristics (S.P. $=43.5-45.8)$. with increasing softening point while in contrast, the asphaltene content increases with softening point. The profiles for both IA and the resins content follow the same trend rising and falling with increasing softening point.

\subsection{The Colloidal Instability of the Asphalts}

Asphalt is a colloidal system with the asphaltenes dispersed in the maltenes. When assessing the colloidal stability of asphalts, the most important factor taken into account is the content of the asphaltenes. Recent studies have looked closely into the chemical composition and structure of asphaltenes [21, 24, 39, 40-44]. Thus, the two asphalt indices;
$\mathrm{I}_{\mathrm{A}}$ and $\mathrm{I}_{\mathrm{C}}$, which bear direct relationship to the content of asphaltenes can be conveniently used to estimate the extent of colloidal stability. These indices have been plotted against asphaltene content in Figures 5 and 6. It is clearly seen in Figure 5 that both $\mathrm{I}_{\mathrm{A}}$ and $\mathrm{I}_{\mathrm{C}}$ increase correspondingly with increasing asphaltene content for oxidized asphalts $($ S.P. $=49)$. It has already been established that the colloidal stability of an asphalt decreases with increase in asphaltene content [43]. The increasing values of these two indices reflect the instability of the oxidized asphalts. Consequently, the instability of these asphalts can be improved by reducing the content of asphaltenes. However, a different picture is obtained in Figure 6 for fresh Chinese residual asphalts

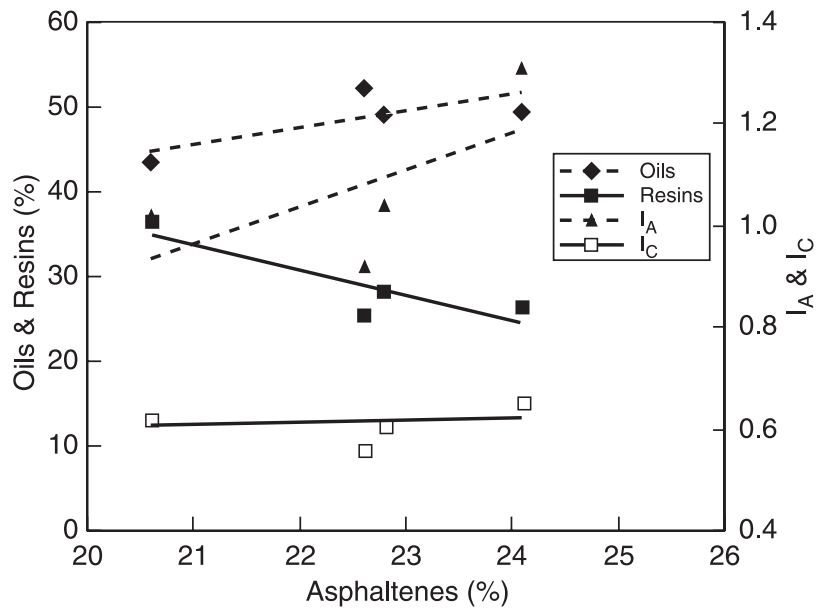

Figure 5

Compositional relationship of asphalts $\left(\right.$ S.P. $\left.=49^{\circ} \mathrm{C}\right)$.

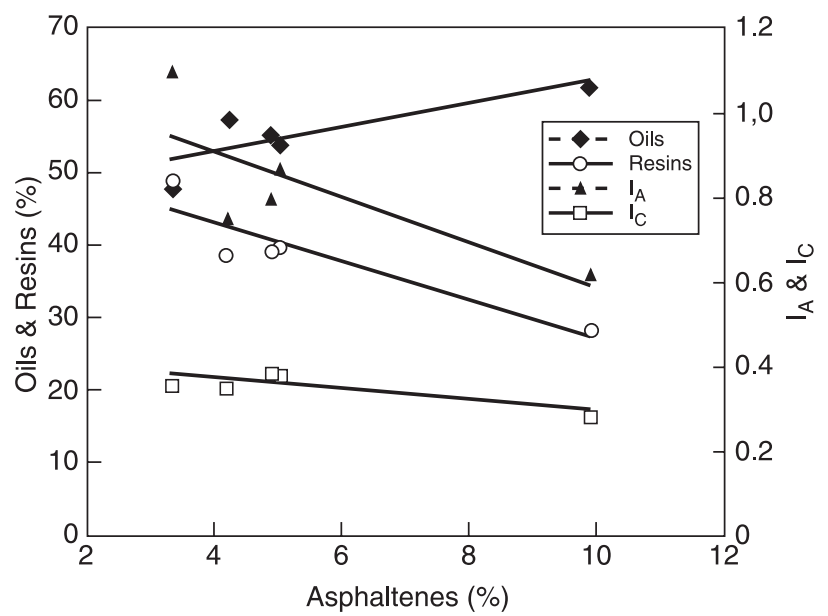

Figure 6

Compositional relationship of residual asphalts $\left(\mathrm{S} . \mathrm{P} .=43.5-45.8^{\circ} \mathrm{C}\right)$. 
where the two asphalt indices, $\mathrm{I}_{\mathrm{A}}$ and $\mathrm{I}_{\mathrm{C}}$, decrease with increase in the content of asphaltenes showing that residual asphalts exhibit comparatively higher colloidal stability than oxidized asphalts.

Figure 7, showing the direct correlation between the two asphalt indices $\mathrm{I}_{\mathrm{A}}$ and $\mathrm{I}_{\mathrm{C}}$, is another confirmation of the suitability of the various composition parameters employed in the study of asphalts. This indicates that the two indices can be conveniently used to evaluate the stability of asphalts.

A further proof is revealed in Figures 8 and 9 showing the dependence of the two asphalt indices on the softening point. The common feature of these plots is the direct relationship between the indices $\mathrm{I}_{\mathrm{A}}$ and $\mathrm{I}_{\mathrm{C}}$ together with the softening

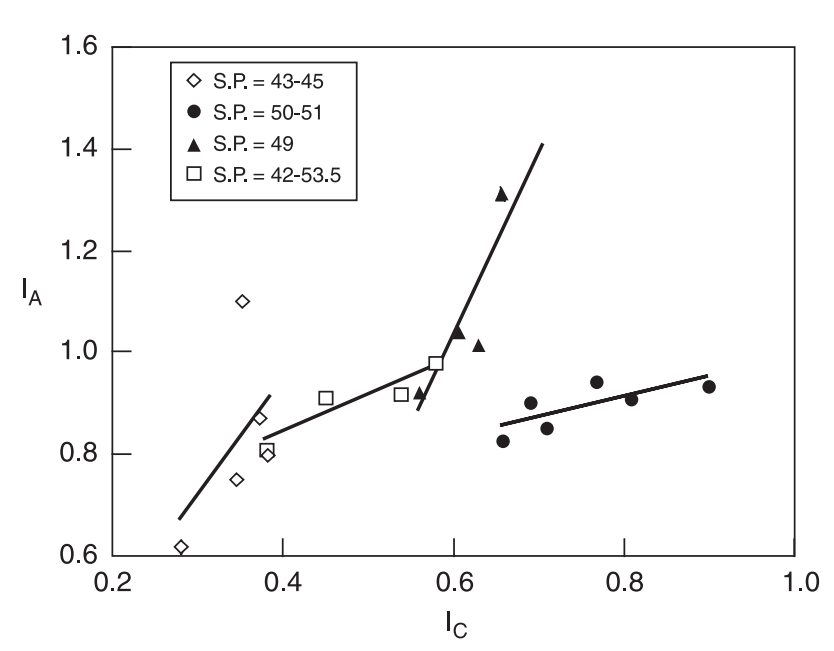

Figure 7

Relationship between asphalt indices. point. A distinguishing feature of these two plots is that both indices recorded positive slopes for oxidized asphalts indicating their colloidal instability and negative slopes for residual asphalts reflecting their colloidal stability. It also follows from these results that the colloidal stability is a direct function of the softening point; the higher the softening point of an asphalt, the greater is the colloidal instability of such an asphalt for oxidized asphalts. The reverse is the case for residual asphalts.

\section{CONCLUSION}

The most common physical properties of petroleum asphalts and their compositional analysis were studied in this work. The main objective of the investigation is to improve upon the understanding of the relationship between the physical characteristics of asphalts and their most important chemical composition: asphaltenes, oils and resins. Interpretation of the results for various asphalts shows that this has been achieved leading to the development of some useful correlation.

Ductility was found to have a non-linear relationship with the content of resins. All the compositional parameters and the two asphalt indices, $\mathrm{I}_{\mathrm{A}}$ and $\mathrm{I}_{\mathrm{C}}$, show some good correlations with the softening point. These correlations can be conveniently applied to determine the colloidal stability of petroleum asphalts. It is concluded that oxidized asphalts exhibit greater colloidal instability than the residual asphalts.

The present study reveals that a good knowledge of the chemical composition of asphalts can provide a useful tool for distinguishing between asphalts of the same origin produced by different methods and having very narrow softening point ranges.

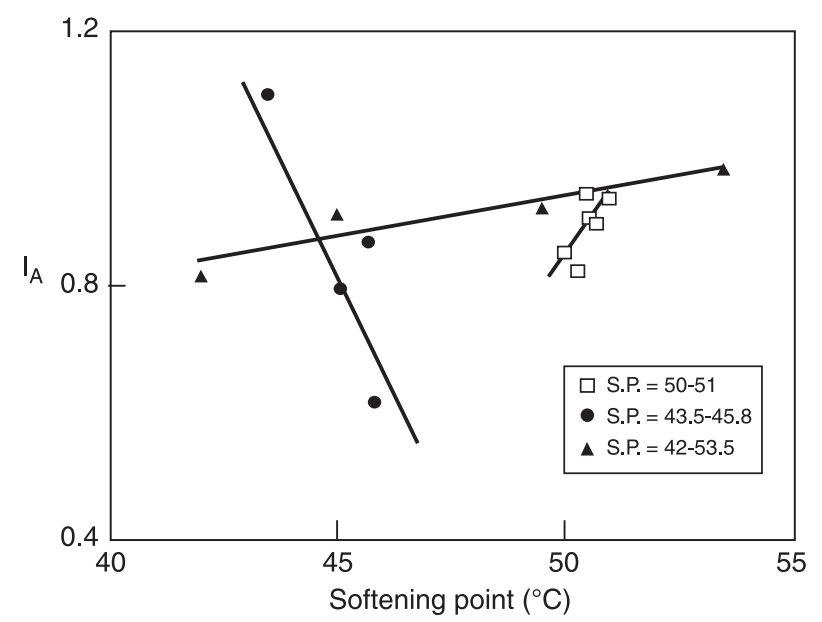

Figure 8

Relationship between $\mathrm{I}_{\mathrm{A}}$ and softening point (open symbols: oxidized asphalts, full symbols: residual asphalts).

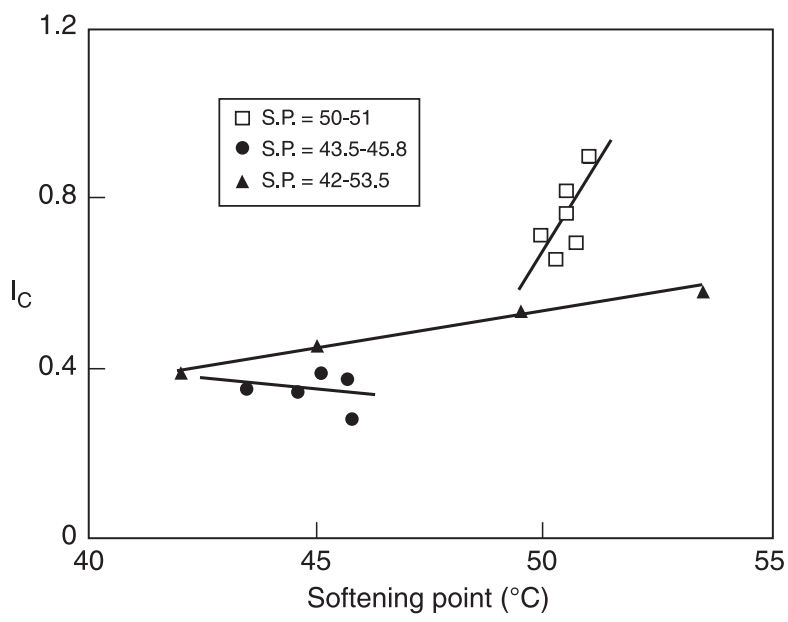

Figure 9

Relationship between $\mathrm{I}_{\mathrm{C}}$ and softening point (open symbols: oxidized asphalts, full symbols: residual asphalts). 


\section{REFEREN CES}

1 Nelson, W.L. (1958) Evaluation of Oil Stocks. Petroleum Refinery Engineering, 4th ed., Mc Graw-Hill, New York.

2 Gun, R.B. (1973) Chapters I-III, Petroleum Bitumens (in Russian), Moscow: Khimiya.

3 Broome, D.C. (1973) Bitumen, in Modern Petroleum Technology, Hobson, G.D., Pohl, H. (eds). 4th ed., IP: Applied Science Publishers Ltd, Barking, Essex, England. 805-815.

4 Marvillet, J. (1975) Influence of Asphalt Composition on its Rheological Behavior. Proc. Assoc. Asphalt Paving Technology, 44, 416-443.

5 Oyekunle, L.O. (1975) Investigation of the Mutual Relationship between the Composition and Properties of Petroleum Bitumens with the Aim of Selecting of a Key Quality Parameter for Process Control. M. Sc. Thesis, Moscow Institute of Oil and Gas, Moscow.

6 Vinogradov, G.V., Isayev, A.I., Zolotarev, V.A. and Verebskaya, E.A. (1977) Rheological Properties of Road Bitumens. Rheologica Acta, 16, 3, 266-281.

7 Al-Farkh, Y.A., El-Rayyes, N.R. and Al-Zaid, K.A. (1978) Studies on Kuwait Crudes. 1. Composition Analysis of Some Asphalts and Their Sulfurized Products, Ind. Eng.Chem. Prod.Res. Dev., 17, 2, 165-169.

8 Varfoolomev, D.F., Friyazimov, V.V., Pechniyi, B.G. and Suniyaev, Z.I. (1981) Perspektivy proisvostva i premenenie ostatochnykh bitumov otechestvennykh neftei (Perspectives of the production and uses of residual asphalts from national crude oils) Central Scientific Research Institute TSNIITE neftekhim, seriya "pererabotka nefti", Moscow.

9 Akhmetova, R.S. and Ivchenko, E.G. (1977) Quality Indices of Residual Asphalts as Related to Properties of Original Crude Oils. Khimiya I Tekhnologiya Topliv I Masel, No. 3, 26-29.

10 ASTM Standards (1998) American Society for Testing and Materials, Philadelphia. Annual Handbook on Petroleum Products and Lubricants. D5, D36, D113, D3279.

11 Thomas, W.H. (1973) Quality Assessment, in Modern Petroleum Technology, Hobson, G.D., Pohl, H. (eds). 4th ed., IP: Applied Science Publishers Ltd, Barking, Essex, England. 855-872.

12 Curtis, C.W., Jeon, Y.W. and Clapp, D.J. (1989) Adsorption of Asphalt Functionalities and Oxidized Asphalts on Aggregate Surfaces. Fuel Science \& Technology International, 7, 9, 1225-1268.

13 Jennings, P.W. and Pribanic, J.A.S. (1989) A Perspective on Asphalt Chemistry Research and the Use of HP-GPC Analysis. Fuel Science \& Technology International, 7, 9, 1269-1287.

14 Halagen, A.P., Johnson, M.P. and Pandolf, B.B. (1989) 13C NMR Studies on Roadway Asphalts. Fuel Science \& Technology International, 7, 9, 1289-1326.

15 Green, J.B., Reynolds, J.W. and Yu, S.K.-T. (1989) Liquid Chromatographic Separations as a Basis for Improving Asphalt Compositions-Physical Property Correlations. Fuel Science \& Technology International, 7, 9, 1327-1363.

16 Barre, L., Espinat, D., Rosenberg, E. and Scarsella, M. (1997) Colloidal Structure of Heavy Crudes and Asphaltenes. Oil \& Gas Science and Technology, IFP, 52, 2, 161-175.

17 Madrid, R.C., Davison, R.R. and Glover, C.J. (2000) Compositional Evaluation of Asphalt Binder Recycling Agents. Petroleum Science and Technology, 18, 153- 175.
18 Andersen, S.I. and Speight, J.G. (2001) Petroleum Resins: Separation, Character and Role in Petroleum. Petroleum Science and Technology, 19, 1\&2, 1-34.

19 Bragado, G.A.C., Guzmán, E.T.R. and Yacamán, M.J. (2001) Preliminary Studies of Asphaltene Aggregates by Low Vacuum Scanning Electron Microscopy. Petroleum Science and Technology, 19, $1 \& 2,45-53$.

20 Donaggio, F., Correra, S. and Lockhart, T.P. (2001) Precipitation Onset and Physical Models of Asphaltene Solution Behavior. Petroleum Science and Technology, 19. $1 \& 2,129-142$.

21 Groenzin, H. and Mullins, O.C. (2001) Molecular Size and Structure of Asphaltenes. Petroleum Science and Technology, 19, $1 \& 2,219-230$.

22 Murgich, J. and Strausz, O.P. (2001) Molecular Mechanics of Aggregates of Asphaltenes and Resins of the Athabasca Oil. Petroleum Science and Technology, 19, 1\&2, 231-243.

23 Ortega-Rodriguez, A., Lira-Galeana, C., Ruiz-Morales, Y. and Cruz, S.A. (2001) Interaction Energy in Maya-Oil Asphaltenes: A Molecular Mechanics Study. Petroleum Science and Technology, 19, 1\&2, 245-256.

24 Demirba, A. (2002) Physical and Chemical Characterizations of Asphaltenes from Different Sources. Petroleum Science and Technology, 20, 5\&6, 485-495.

25 Yang, P., Yan, F., Liu, D., Wei, Y. and Liao, K. (2002) Preparation of Heavy Paving Asphalt by Blending-Oxidizing Anshan Vacuum Residue and the Evaluation of its Paving Performance. Petroleum Science and Technology, 20, 5\&6, 549-559.

26 Ali, M.A. and Hassan, A. (2002) Hydrocarbon Group Types Analysis of Petroleum Products: A Comparative Evaluation of HPLC and TLC Analytical Performance. Petroleum Science and Technology, 20, 7\&8, 751-762.

27 Ruan, Y, Davison, R.R. and Glover, C.J. (2003) An Investigation of Asphalt Durability: Relationships between Ductility and Rheological Properties for Unmodified Asphalts. Petroleum Science and Technology, 21, 1\&2, 231254.

28 Qi, Y. and Wang, F. (2003) Study and Evaluation of Aging Performance of Petroleum Asphalts and Their Constituents During Oxygen Absorption. I. Oxygen Absorption Behaviors and Kinetics. Petroleum Science and Technology, 21, 283299.

29 Gawrys, K.L., Spiecker, P.M. and Kilpatrick, P.K. (2003) The Role of Asphaltene Solubility and Chemical Composition on Asphaltene Aggregation. Petroleum Science and Technology, 21, 3\&4, 461-489.

30 Ibrahim, Y.A., Abdelhameed, M.A., Al-Sahhaf, T.A. and Fahim, M.A (2003) Structural Characterization of Different Asphaltenes of Kuwaiti Origin. Petroleum Science and Technology, 21, (5\&6), 825-837.

31 Vallerga, B.A. (1987) Emulsified Petroleum Oils and Resins in Reconstituting Asphalts in Pavements. http://www.bridgeasphalt.com

32 Pruett, R.L. (1987) The Role of Rejuvenators in Asphalt Pavement Maintenance. 5th Annual Texas Airport Operators Conference, April 9.

33 Boyer, R.E. (2000) Asphalt Rejuvenators: Fact or Fable. Transportation Systems 2000 (TS2K) Workshop, San Antonio, Texas, Feb. 28-March 3.

34 Yang, P., Cong, Q. and Liao, K. (2003) Application of Solubility Parameter Theory in Evaluating the Aging Resistance of Paving Asphalts. Petroleum Science and Technology, 21, 11\&12, 1843-1850. 
35 Qi, Y. and Wang, F. (2004) Study and Evaluation of Aging Performance of Petroleum Asphalts and Their Constituents During Oxygen Absorption II. Chemical Group Composition and Structure Changes. Petroleum Science and Technology, 22, 263-274.

36 Qi, Y. and Wang, F. (2004) Study and Evaluation of Aging Performance of Petroleum Asphalts and Their Constituents During Oxygen Absorption. III. Average Molecular Structure Parameter Changes. Petroleum Science and Technology, 22, $3 \& 4,275-286$.

37 Cong, Y., Huang, W., Liao, K., Liu, G., Yang, Y. and Liu, J. (2004) Study on Composition and Structure of Liaoshu Asphalt. Petroleum Science and Technology, 22, 3\&4, 455462.

38 Lima, F.S.G. and Leite, L.F.M. (2004) Determination of Asphalt Cement Properties by Near Infrared Spectroscopy and Chemometrics. Petroleum Science \& Technology, 22, $3 \& 4,589-600$.

39 Ali, M.F., Siddiqui, M.N. and Al-Hajji, A.A. (2004) Structural Studies on Residual Fuel Oil Asphaltenes by RICO Method. Petroleum Science and Technology, 22, 5\&6, 631- 645.

40 Gawel, I. (1987) Structural Investigation of Asphalts Produced from Paraffinic-base Crude Oil by Different Methods. Fuel, 66, 618-621.

41 Gawel, I. (1993) Relationship between the Production Method and the Properties and Composition of Bitumens. In Proceedings of the 5th Eurobitume Congress, Stockholm, Sweden, 175-17.

42 Baginska, K. and Gawel, I. (1997) The Chemical Structure and Properties of Bitumens of Different Origin. Petroleum and Coal, 39, 50-51.

43 Baginska, K. and Gawel, I. (2004) Effect of Origin and Technology on the Chemical Composition and Colloidal Stability of bitumens. Fuel Processing Technology, 85, 1453-1462.

44 Gawel, I. and Baginska, K. (2004) Effect of the Chemical Nature on Susceptibility of Asphalt to Aging. Petroleum Science and Technology, 22, 1261-1271.

45 Alboudwarej, H., Jakher, R.K., Svrcek, W.Y. and Yarranton, H.W. (2004) Spectrophotometric Measurement of Asphaltene Concentration. Petroleum Science and Technology, 22, 5\&6, 647-664.

46 Oyekunle, L.O. (1977) Processing Atmospheric Residues of Nigerian Crudes. Proceedings of the Nigerian Society of Chem. Engrs. University of Ife, Ife, 255-286.
47 Oyekunle, L.O. (1980) Rheological Properties of Petroleum Bitumens. Proceedings of the Nigerian Society of Chem. Engrs. University of Benin, Benin, 56-75.

48 Oyekunle, L.O. (1982) Lubricating Oil and Bitumen Production from Nigerian Crudes. Proc. of the Nig. Soc. of Chem. Engrs. University of Lagos, 160-170.

49 Oyekunle, L.O. (1983) Properties of Petroleum Bitumens. Journal of Nig. Soc. Chem. Engrs., 1, 2, 172-183.

50 Oyekunle, L.O. (1985) Effect of Temperature on Rheological Properties of Petroleum Bitumens. Journal of the Nigerian Society of Chem. Engrs., 4, 124-139.

51 Oyekunle, L.O. and Onyehanere, L.N. (1990) Upgrading of Residual Asphalts: Kinetics of Asphaltene Generation. ANSTI 3rd Chemical Engrs Seminar, Dar-es Salaam, 239244.

52 Oyekunle, L.O. and Onyehanere, L.N. (1991) A Kinetic Study of the Sulphurization of Residual Asphalts. Chemical Engineering Communication, 105, 53-60.

53 Oyekunle, L.O. and Onyehanere, L.N. (1991) Studies on Nigeria Crudes. Analysis of Sulphurized Asphalts. Fuel Science and Technology International, 9, 6, 681-693.

54 Oyekunle, L.O. (2000) A Two-Parameter Correlation for Petroleum Bitumens. Petroleum Science and Technology, 18, $1 \& 2,63-79$

55 Oyekunle, L.O. and Onwa, J.U. (2000) Catalytic Treatment of Petroleum Asphalts. Petroleum Science and Technology, 18, 1\&2, 81-89.

56 Oyekunle, L.O. and Adesanya, A.A. (2000) Chemical Transformation of Residual Asphalts. Petroleum Science and Technology, 18, 1\&2, 91-102.

57 Oyekunle, L.O. and Omatsone, O.O. (2000) Mathematical Modelling of the Rheological Properties of Petroleum Bitumens. Petroleum Science and Technology, 18, 5\&6, 711723.

58 Oyekunle, L.O. and Omatsone, O.O. (2004) Studies on Nigerian Crudes II. Physical Characteristics and Rheological Properties of Residual Asphalts. Petroleum Science and Technology, 22, 5\&6, 701-711.

59 Oyekunle, L.O., Fasae, H.A., Imafidon, J.U., Soile, O.T., Bankole, A.A. and Bello, K.A. (2004) Studies on Nigerian Crudes IV. Improvement of Asphaltic Properties of Residual Asphalts. Petroleum Science and Technology, 22, 9\&10, 227-1249.

Final manuscript received in October 2005

Copyright (C) 2006 Institut français du pétrole

Permission to make digital or hard copies of part or all of this work for personal or classroom use is granted without fee provided that copies are not made or distributed for profit or commercial advantage and that copies bear this notice and the full citation on the first page. Copyrights for components of this work owned by others than IFP must be honored. Abstracting with credit is permitted. To copy otherwise, to republish, to post on servers, or to redistribute to lists, requires prior specific permission and/or a fee: Request permission from Documentation, Institut français du pétrole, fax. +33147527078 , or revueogst@ifp.fr. 